| Research Article / Araştırma Makalesi|

\title{
The Relationship Between the Effectiveness of School Principals in the Communication Process and the Psychological Capital Levels of Teachers During the COVID-19
}

\section{COVID-19 Sürecinde Okul Müdürlerinin İletişim Sürecindeki Etkililiği ile Öğretmenlerin Psikolojik Sermaye Düzeylerinin İlişkisi}

\section{Aydın KARABAY ${ }^{1}$, Mithat KORUMAZ ${ }^{2}$, ibrahim KOCABAŞ ${ }^{3}$}

\author{
Anahtar Kelimeler \\ 1.okul müdürleri \\ 2.iletişim etkililiği \\ 3.psikolojik sermaye \\ 4.öğretmenler \\ 5.salgin
}

\section{Keywords \\ 1. school principals \\ 2. effectiveness of \\ communication \\ 3. psychological capital \\ 4. teachers \\ 5. pandemic}

\section{Received/Başvuru Tarihi}

23.04.2021

Accepted / Kabul Tarihi

30.08.2021

\begin{abstract}
Purpose: This study was conducted to determine the relationship between the effectiveness of school principals in the communication process and the psychological capital of teachers.

Design/Methodology/Approach: The research was conducted in relational research design, one of the quantitative research approaches. The scope of the study consisted of primary, secondary, and high school teachers in the Güngören district of Istanbul province. The stratified sampling method was determined as the sampling method, and the sample consisted of 353 participants. The Scale of Effectiveness of School Principals in the Communication Process and the Short Form of the Psychological Capital Scale were used as data collection tools. The analysis of the data was executed with the SPSS 21 program.

Findings: Correlation analysis was conducted to determine the relationship between the two variables of the study. As a result of the research, a moderate relationship was found between the effectiveness of school principals in the communication process and the psychological capital of teachers. As a result of this, regression analysis was made, and it was determined that the effectiveness of school principals in the communication process explained $13 \%$ of teachers' psychological capital.

Highlights: As a result of the research, it was recommended to organize practical training for school principals and teachers on the use of digital communication platforms due to the pandemic and allocate time for psychological capital and communication
\end{abstract} process during the seminar periods.

Öz

Çalışmanın amacı: Bu araştırma okul müdürlerinin iletişim sürecindeki etkililiği ile öğretmenlerin psikolojik sermayeleri arasındaki ilişkinin tespit edilmesi amacıyla yapılmıştır.

Materyal ve Yöntem: Araştırma nicel araştırma yaklaşımlarından ilişkisel araştırma deseninde yapılmıştır. Araştırmanın evrenin İstanbul ili Güngören ilçesindeki ilkokul, ortaokul ve lise öğretmenleri olușturmaktadır. Örnekleme yöntemi olarak tabakalı örnekleme yöntemi belirlenmiştir ve örneklem 353 katılımcıdan oluşmuştur. Veri toplama aracı olarak Okul Müdürlerinin İletişim Sürecindeki Etkililiği Ölçeği ve Psikolojik Sermaye Ölçeği Kısa Formu kullanılmıştır. Verilerin analizi SPSS21 bilgisayar programıyla yapılmıştır.

Bulgular: Araştırmanın iki değişkeni arasındaki ilişkinin tespiti için korelasyon analizi yapılmış olup araştırma sonucunda oku müdürlerinin iletişim sürecindeki etkililiği ile öğretmenlerin psikolojik sermayeleri arasında orta düzeyde ilişki bulunmuştur. Bunun sonucunda regresyon analizi yapılmış olup okul yöneticilerinin iletişim sürecindeki etkililiğinin öğretmenlerin psikolojik sermayelerinin \%13'ünü açıkladığı tespit edilmiştir.

Önemli Vurgular: Araştırmanın sonucunda salgının bir sonucu olarak dijital iletişim platformlarının kullanımı konusunda okul yöneticilerine ve öğretmenlere uygulamalı eğitimler düzenlenmesi, seminer dönemlerinde psikolojik sermaye ve iletişim süreci konularına zaman ayırılması önerilmiştir.

\footnotetext{
${ }^{1}$ Corresponded Author, PhD student at Yildiz Technical University, Department of Educational Administration, College of Education, Istanbul, TURKIYE; https://orcid.org/ 0000-0002-7897-5049

2 Dr. at Yildiz Technical University, Department of Educational Administration, College of Education, Istanbul, TURKIYE; https://orcid.org/ 0000-0003-1800-7633

${ }^{3}$ Prof. Dr. at Fatih Sultan Mehmet University, Department of Educational Administration, College of Education, Istanbul, TURKIYE; https://orcid.org/ 0000-0002$3540-2427$
}

Citation/Alıntı: Karabay, A., .Korumaz, M., \& Kocabaş, İ. (2021). The Relationship between the effectiveness of school principals in the communication process and the psychological capital levels of teachers during the covid-19, Kastamonu Education Journal, 29(3), 756-768. doi: 


\section{INTRODUCTION}

How many people who had plans for the new year towards the end of 2019 thought that they would spend 2020 like in science fiction movies? As of March 12, 2020, the World Health Organization has declared COVID-19 as a pandemic. Due to the pandemic, many areas such as social life, economic situation, transportation, security, and education have begun to change and transform all over the world (Sucu, 2020). On the other hand, organizations established by people to produce services or goods must also achieve their goals (Keleş, 2011). The uncertainty, fear of health, and death that occurs with COVID-19 create a pessimistic mood in individuals. Therefore, individuals need more hope, an optimistic perspective, an increase in their self-efficacy, and the development of resilience characteristics to cope with the situation, both for themselves and for the organization they belong to (Bolelli, 2020). Educational institutions are among these organizations both in terms of having to continue to achieve their goals and being affected by the pandemic.

Ministry of National Education (MoNE) closed schools after the detection of the virus in Turkey and managed the process generally monthly. Each month, MoNE announced the situations of the schools for the next month. With the 2020-2021 academic year, schools started education gradually, and students started to go to schools in a system called hybrid education. Educational activities continued unusually. Finally, MoNE stated that with the increase of the pandemic again in the mid-term holiday in November 2020, education would continue with distance education until the new year (Ministry of National Education, 2020). It is seen that this situation has not changed in 2021. As can be seen, in the process defined as the "new normal," teachers continue to work individually with distance education. Therefore, it can be said that this situation has increased the importance of their psychological capital more. Because according to Luthans et al. (2004), psychological capital is about the individual, and it means more than traditionally known human capital and social capital for organizations to achieve their goals.

As a result of the categorical research of Erkmen \& Esen (2012) in international studies, a negative relationship was found between psychological capital and employee absenteeism, intention to quit, job-seeking behavior, deviant behavior of employees, stress, rude behavior variables. However, there is a positive relationship between psychological capital and organizational commitment, job satisfaction, positive emotions, organizational citizenship behavior, job performance, employee performance, effectiveness, creative performance, authentic leadership, transformational and transformational leadership, quality of life, positive organizational climate, sales revenue, and achieving goals.

According to Tösten \& Özgan (2017), psychological capital has been studied mainly in business administration until 2013, and there has been limited studies on education management until then. According to the results of the research conducted by Tösten and Özgan (2017) in the field of education, teachers' perceptions of psychological capital were found to be high. During the COVID19 , it is seen that psychological capital is not yet the subject of research in the field of education. On the other hand, it is seen that the only research related to the subject in this process was conducted by Bolelli (2020) in the field of business administration on psychological capital and subjective well-being, and a significant positive correlation was found between these two variables.

In researches on education during the COVID-19, problems with communication stand out. During the COVID-19, Külekçi and Akyavuz (2020) identified communication problems as the most experienced problem by school principals, and according to Akyavuz and Külekçi (2020), this problem experienced by teachers, too. Furthermore, Külekçi Akçakın and Yavuz (2020) listed technical inadequacies, insufficient feedback, lack of feedback, and listed failure to establish face-to-face communication and the absence of internet or connection problems as the reason of the communication problem.

Communication is a very important feature in the success of the principal, who has many different duties and responsibilities within the school (Çınar, 2010). Because, according to Batty (1978), managers spend 75\% to 95\% of their time (Koçel, 2018), 80\% according to Mintzberg, and $70-80 \%$ according to Reginald (Orsntein \& Lunenberg, 2013). For this reason, the effectiveness of school principals in the communication process is important to communicate well with teachers and to reach the goals of the school (Çınar, 2010).

In the light of the above, during the COVID-19, where people experience negative emotions, the effectiveness of school principals in the communication process and the level of teachers' psychological capital have become even more important to achieve the goals of education. The effectiveness of school principals in the communication process can be explained in the context of a psychological perspective. The psychological perspective is one of the approaches that explain organizational communication (Durğun, 2006). Employees' need for positive emotions has increased as all people need during the pandemic period. The broaden and build theory suggests that positive emotions enhance employees' individual resources (Frederickson, 2001). On the other hand, it is seen that psychological capital, which is one of the individual resources (Gorgievski, Halbesleben \& Bakker, 2011) with its measurable and developmental feature, has been handled with many variables in the field, but it is not addressed with communication. During the COVID-19, where communication becomes more important, and afterward, determining its relationship with the communication variable is considered important. Therefore, in the study, it was aimed to determine whether the effectiveness of school principals in the communication process predicted teachers' psychological capital. At the end of the study, it is hoped that the school principals will raise awareness about the effect of teachers' psychological capital with the communication variable and, in this context, their effectiveness in communication processes in achieving the school's goals.

\section{Organizational Communication}

| Kastamonu Education Journal, 2021, Vol. 29, No. 3| 
Communication is the process of passing information, ideas and emotions from one person to another (Eren, 2017), producing, transferring and making sense of information (Dökmen, 2006), exchanging meaning (Cüceloğlu, 2002), making common meanings (Kocabaş, 2014). In other words, it is the process of passing news according to pre-accepted symbols-symbols between individuals and units (Taymaz, 2011). In the context of educational management, communication is a process of mutual interaction involving the school principal's message sent to the subordinate to influence them and also involves the subordinates' responses to the superior (Başaran, 1994).

A communication process consists of seven elements: the sender, the sender's and the receiver's perception and evaluation styles, message, channel, receiver, feedback, and noise (Eren, 2016). The sender is called the source that sends the message or (Hoy \& Miskel, 2015) the person who conveys meaning to another person to achieve a goal (Başaran, 1994).

The receiver is the people to whom the message is intended to be delivered (Önen, 2016). For the sender to communicate effectively while delivering the message, it is necessary to use concrete, conventional symbols in accordance with the knowledge and experience of the receiver. The words that will potentially cause confusion should be explained (Eren, 2017). On the other hand, the sender should take into account the values, goals, and environment of the receiver because individuals think and perceive messages according to themselves. Otherwise, the superior sometimes does not transmit the entire message, thinking that the subordinates can understand the message clearly, which may damage the effectiveness of the communication (Eren, 2016).

The message is the symbol that reveals the sender's ideas, thoughts, desires, attitudes, and wishes (Koçel, 2018). In effective communication, if the message is given closed to interpretation (Kocabaş, 2014) and awakens the same things in both the sender and the receiver, it means that it reaches the target exactly. If this does not happen, the quality of communication will decrease (Eren, 2016). Another element of the communication process is the channel, the way the message is carried from the sender to the receiver (Koçel, 2018). If communication is face to face, it reaches the receiver through the air with the help of words and sound. If it is with a telephone, it will be satellite signals, or if it is via other means of devices as a result of the development of technology, it is various channels (Önen, 2016). It is possible to say that the most important element to make sense of whether this whole process works correctly or not is the feedback.

Feedback is the message sent as a response to the first message, which facilitates their interpretation or allows them to make corrections (Hoy \& Miskel, 2015). It can also be defined as a response of the receiver to the sender to see whether the message is fully understood or not. This means that each receiver is also a sender (Koçel, 2018). Feedback has benefits in management, such as increasing the effectiveness of communication by ensuring regular and continuous communication, motivating individuals, working as a team, reinforcing their behavior, and being more efficient. It also helps to check whether the results are achieved and the results targeted by the communication are consistent (Coffey, Cook \& Hunsaker, 1994, as cited in Koçel, 2018).

Finally, noise is anything that reduces the accuracy or reliability of communication. If the message is not explained with meaningful, sufficient symbols, noise will occur. The message may contain unnecessary repetitions, misspellings, or other errors (Eren, 2016). The effectiveness of communication processes can be expressed as the compatibility of the elements mentioned above. On the other hand, the influence of the direction of communication cannot be denied in this process.

When the literature is reviewed, communication in the organization is listed as hierarchically downward communication, upward communication, lateral communication, and cross-communication. In downward communication, information, opinions, suggestions, and orders are transferred quickly from superiors to subordinates. It is an important and widely used form of communication for management effectiveness (Erdoğan, 2014). Communication comes down from the superior, easy to implement but inadequate in some ways. For example, subordinates choose directives that will prioritize them based on the character and style of the manager, or they do not spend enough time and effort in obtaining information that the message from the superior has been received and understood. Another is that the upper hierarchy hides basic information on certain topics by closing the communication channel (Lunenburg \& Ornstein, 2013).

Upward communication enables information to move from the lower unit to the upper unit in the organization. In this communication, correct communication is difficult for many reasons. One of the reasons is that subordinates hide information from their superiors that could potentially harm their careers. If the subordinate does not trust the superior, the rate of information retention may increase even more. Another reason is the practice of censorship in transferring information to the superiors of the subordinates because compatible groups harm the group (Canary, 2011, as cited in Lunenberg \& Ornstein, 2013). Besides, the physical distance between subordinates and superiors, inability to reach or change information at hierarchical levels during the flow of information from lower to upper levels can be added (Kocabaş, 2014). On the other hand, this communication has benefits such as showing whether the decisions sent from superior are adopted by the subordinates, encouraging members of the institution to contribute to the institution by identifying with the goals and programs of the institution, preventing undesirable situations in the management and promoting the development of internal democracy (Erdoğan, 2014)

Lateral communication becomes a necessity, especially in cases such as the excessive specialization or growth of organizations (Kocabaş, 2014). The main purpose of lateral communication is to coordinate tasks, solve problems, share information with colleagues, resolve conflicts and create friendly relations (Harris, 1993, as cited in Hoy \& Miskel, 2015). An example of this is that school principals communicate with each other and exchange ideas about what they are doing at their schools. While the task 
ensures coordination, lateral communication also serves as a socialization process for the organization by providing emotional and social support among peers (Lunenberg \& Ornstein, 2013).

Diagonal is important when participants cannot communicate effectively through other channels. For example, the deputy manager of the urban school district may want to analyze a curriculum cost for each high school. In one part of the analysis, it would cross-cross the communication if the school district deputy principal chooses to send special reports directly to each school principal - rather than the traditional detours (Lunenburg \& Ornstein, 2013).

In the subtitle of organizational communication, the communication process and the direction of communication in the organization is mentioned. According to Özmen and Yörük (2007), cited from Giannantonio (2002), 21st-century organizations will be formed from individuals with high communication skills. Communication skills are one of the most important skills of an effective organizational manager. In this context, it can be said that school principals should be chosen of people who can be active in the communication process in this century.

School principals should use some strategies to maintain effective communication. These strategies are to cooperate with the leaders in the environment and to ensure the participation of those around, to motivate the participants, to reveal the achievements, to repeat important news, to prevent rumors by putting forward the facts against rumors, to know the communication barriers, to benefit from all communication tools, to recognize support and opposing forces and to communicate uninterruptedly (Bursalıoğlu, 2015). Also, a school principal should be a role model for his staff (Karaköse \& Kocabaş, 2009) in terms of communication. It can be said that the main purpose of the school principal who uses these strategies is to achieve the goals of the school. According to Acaray (2018), it is possible for managers to provide an effective communication process in the organization and to achieve organizational success by sending the right information to the right receivers at the right time.

As the result of COVID-19, the communication process in schools also requires to be carried out on digital platforms, so it also requires school principals to carry out the communication process effectively on these platforms to achieve the goals of the school as an organization. Also, since the necessity of maintaining an isolated life as a result of the pandemic brings an individual working style, it is thought that the importance of communication skills of school principals increased more. It can be said that the increase in individual work has increased the importance of employees' individual resources. In managing the distance education process, it is thought that the effectiveness of the communication process of school principals is related to teachers' psychological capital, which is an individual resource.

\section{Psychological Capital}

With the Second World War, the direction of psychology started to change. After the Second World War, the paradigm of psychology started to change. It can be said that after the war, to solve psychological problems, psychologists started to focus on the strengths of individuals rather than the negatives. Because psychology is a science that not only treats weaknesses, damages, and ailments but also deals with strengths, development, education, and love (Seligman, 2002). Maslow and Rogers have criticized the field of psychology, which constantly focuses on negative aspects. As a result of their studies, the field of psychology has started to focus on the positive aspects of individuals. According to them, the important characteristics of being human, such as love, creativity, and a tendency to develop, are ignored (Gillham \& Seligman, 1999). As a result of the change of perspective, positive psychology is a concept that Seligman and his colleagues laid the foundation of in the early 2000s. Positive psychology is a scientific and clinical intervention that deals with the determination of factors that improve well-being and is a branch of psychology used to understand and improve the positive aspects of life (Carr, 2015).

Psychological capital is a concept derived from the positive psychology trend. Psychological capital is about improving the advantage of capital owned in the workplace for competition because managers now realize that not only money is enough, but human capital is also important, and therefore they have started to think about the development of this capital (Luthans \& Youssef, 2004). Psychological capital deals with the question of "who you are" rather than the questions of "what do you have" of traditional economic capital, "what do you know" of human capital, and "who do you know" of social capital (Luthans et al., 2004).

Psychological capital has four sub-dimensions: self-efficacy, hope, optimism, and resilience. Self-efficacy refers to a person's belief in activating his/her cognitive capacity to achieve certain goals. It is a developmental feature, as Bandura tells us about in his workplace studies (Luthans \& Youssef, 2014). Leaders who are respected in the organization, using the language, can develop the self-efficacy capacity of employees' psychological capital through persuasion (Luthans et al., 2004). In this context, it is thought that the attitude of school principals in the communication process is important. Because, according to Luthans et al. (2004), statements such as "you can" have positive effects in increasing trust, while negative statements such as "you cannot" have negative effects.

Although fewer studies have been done on hope than other sub-dimensions, it is a sub-dimension that the results of the studies conducted in the workplace have both an academic and sportive effect on performance. Hope refers to the individual's strong will to achieve their goals (Luthans \& Youssef, 2004). Luthans and Jensen (2002) identified several steps to improve the hope of employees in organizations. These steps can be expressed as determining personal and organizational goals challenging and clearly, breaking these goals into small steps if employees' hopes are low, making action plans for the purpose, being ready for obstacles and finding solutions, preparing alternative plans, and setting new targets when necessary (Luthans et al., 2004). The importance of school principals in determining and conducting these steps in school organizations cannot be denied. In this context, it is thought that school principals should be effective in the communication process to improve teachers' hopes. 
Optimism, another component of psychological capital, is to have positive thoughts about the individual's success, now and in the future (Luthans et al., 2006). Optimism is a sub-dimension that can be associated with psychological capital more than others, thanks to the studies of Seligman. According to Seligman's (1998) studies at the workplace, he/she found that sales were positively affected as a result of the optimism of the sales representatives. According to Luthans et al. (2004), optimists consider bad events as a temporary process (tired); pessimists interpret it as a permanent process (I am destroyed). Considering that school principals spend most of their time at school through communication, it is estimated that the language they use is important in teachers' optimism levels.

Resilience is the power to overcome difficulties, failures, and even overwhelming positive change (Luthans \& Youssef, 2014). As clinical and positive psychology put forth, it is a sub-dimension that will contribute positively to workplace performance. Additionally, it is the capacity to make positive changes in the turbulent environment of today's business world (Luthans et al., 2004). Considering the functioning of schools during the COVID-19, it is believed that schools as an organization are also in a turbulent process, so the contribution of teachers' resilience capacities in the positive management of the process cannot be ignored. The effectiveness of school principals in the communication process can contribute to the resilience of teachers against the uncertainties brought by the pandemic, the possible problems of distance education, and the stress that it may bring to teachers. In this context, according to Luthans et al. (2004), preventing negative thoughts when things go wrong, testing the accuracy of thoughts about problems and finding useful solutions, staying calm, and focusing in times of overwhelming emotions or stress are steps to be taken to improve the resilience of employees.

With these sub-dimensions, positive psychological capital has characteristics such as being unique, measurable, developmental, and affecting performance (Luthans \& Youssef, 2004). Being measurable and developmental is an important characteristic of psychological capital. For this reason, managers who want to increase the efficiency of their organizations should find the strengths, weaknesses, positive and negative aspects of the individuals they work with and take measures to improve them. So they need to invest in their psychological capital (Keleş, 2011). In short, during the COVID-19, the functioning of life started to change in various ways.

Educational organizations have also been affected by this change. Effective communication has become an even more important responsibility of school principals, who normally spend most of their work in communication. This situation reveals the necessity of conducting an effective communication process to achieve the goals of the school, which is one of the educational organizations. On the other hand, the fact that teachers have to work remotely and take on more individual responsibilities has also increased the importance of psychological capital, which means more than traditional concepts such as human capital and social capital. For this reason, it is thought that the relationship between the effectiveness of the communication process in which school principals spend so much time and the psychological capital of teachers is important. In this context, the following questions were sought in the research:

1. What is the level of teachers' perception of the effectiveness of the communication process of school principals?

2. What is the psychological capital level of teachers?

3. Do teachers' perceptions of the effectiveness of the communication process of school principals differ according to school levels?

4. Do teachers' psychological capital differ according to their school levels?

5. Do teachers' perceptions of the effectiveness of the school principals' communication process and the psychological capital levels of teachers show a significant relationship?

6. Do teachers' perceptions of school principals' communication process effectiveness significantly predict teachers' psychological capital levels?

\section{METHOD}

The information about the method and other details is explained in this section.

\section{Research Design}

The research has been carried out with a quantitative research approach and is in a relational survey pattern. Relational studies reveal the relationships between two or more variables (Sönmez \& Alacapınar, 2014) without affecting them in any way (Fraenkel \& Wallen, 2009), providing the opportunity to make predictions about the results (Creswell, 2012) and the opportunity to analyze these relationships in-depth (Karakaya, 2014). In this study, as it was examined whether the effectiveness of school principals in the communication process is related to teachers' psychological capital, it was deemed appropriate to design the study as relational research. In relational research, the relationship between the independent variable of the research and the dependent variable is examined in a correlational manner (McMillan \& Schumacher, 2014). In this context, this study examined whether the effective communication processes of school principals as an independent variable during the COVID-19 pandemic significantly predicted the psychological capital levels of teachers as the dependent variable of the study.

\section{Scope of the Study}


The scope of the research consisted of teachers working in the Güngören district of Istanbul province. The population is the beginning of which the research is intended to be generalized, and it is defined according to certain criteria. Those who meet these criteria constitute the more concrete study scope, which is called the population that can be reached (Karasar, 2016). The study scope of the research consisted of teachers working in official primary, secondary, and high schools in the Güngören district of Istanbul province. According to Ekiz (2015), the population of the study refers to the whole that can be generalized through sampling since it is often difficult to reach the entire study scope; it is studied with a sample called a small cluster, which is selected from the relevant scope according to certain criteria and can represent the population (Karasar, 2016). The sampling type of this research is random sampling. The reason for using the random sampling method is to be able to generalize objectively because the basic rule for the sampling to be generalized to the population is neutrality (Karasar, 2016). Therefore, the stratified sampling method, which is one of the random sampling methods, was used in the study to make an unbiased generalization. According to Ekiz (2015), stratified sampling is the selection of participants to represent the population by looking at their specific characteristics. In the stratified sample, the study scope is divided into certain strata according to the characteristics of the units in the population. Subsequently, the sample of the research is created by taking the proportions of the strata in the study population into consideration to represent the strata at the same rate. At this point, randomness is achieved by choosing the units randomly from each layer (Yamane, 2006). According to Şahin (2014), using the appropriate method ensures that the sample is valid, reliable, and has a high representation power. In this context, it is thought that the sampling method used for this research in the relational survey design coincides with the aims of the research and is suitable for generalization to the population. Therefore, it can be said that the stratified sample increases the validity, reliability, and external validity of the study together with its power to represent the population.

The strata in the study were determined according to the grades of the schools. According to the National Education Basic Law No. 1739, schools are divided into levels according to the development levels of the students, and the establishment and functioning of the levels may differ from each other (Mevzuat, 2020).

According to the regulations of the Ministry of National Education for preschool and primary education institutions, all classes except Religious Culture and Moral Knowledge and English lessons must be taught by primary school teachers in primary schools. However, if no teachers from these branches can be found under any circumstances, these courses can also be taught by the teacher of the class (Mevzuat, 2020). In this context, classroom teachers have responsibilities for only one class, and they spend the whole week, month, or even year with the class they are responsible for. Also, the same law states that it is essential that classroom teachers teach the same class in the following year. In this respect, it is thought that the level of their psychological capital will reflect on the class for which they are responsible.

On the other hand, branch teachers in secondary and high schools take the responsibility of more students by teaching different classes. In this respect, it is estimated that the level of their psychological capital will affect a large number of students. For this reason, stratified sampling was preferred, as it is important to examine the relationship between school principals 'effective communication process and teachers' psychological capital. Therefore, three layers were determined as primary school, secondary school, and high school in accordance with the population of the study. Thus, it was examined whether there was a difference between these grades in accordance with the purpose of the research. As of the fall semester of 2020, a total of 1595 teachers were working in Istanbul province, Güngören district, 583 in public primary schools, 506 in secondary schools, and 506 in high schools (Güngören District Governorship, 2020). In this study, according to the number in the population of the study, the sample size should not be less than 316 (Yamane, 2006). Accordingly, it was necessary to reach 114 teachers corresponding to $36 \%$ from primary schools and 102 teachers corresponding to 32\% from secondary and high schools.

\section{Data Collection and Tools}

In this study, the Effectiveness of School Principals in the Communication Process Scale (ESPCPS) developed by Özmen and Yörük (2007) was used as a data collection tool. The scale consists of 18 items, 6 of which are negative and 12 of which are positive, and it is a one-dimensional scale. Also, the Cronbach Alpha internal consistency coefficient of the scale was determined as .90.

On the other hand, the Psychological Capital Scale Short Form (PCSSF) adapted to Turkish by Oruç (2018) was used to examine teachers' psychological capital. The scale is 12 items. It consists of 4 sub-dimensions: self-efficacy, hope, resilience, and optimism. The Cronbach Alpha internal consistency coefficient of the scale was found to be .93. Both scales are in Likert type, and the ESPCPS was prepared as a 5-point Likert, and the PCSSF was prepared as a 6-point Likert. Two experts examined the scales whether they were appropriate to be used in the scope of the research and also their suitability in terms of appearance validity.

The data collection phase was completed via e-mail on the internet. While writing the items of the scales, all items were marked as mandatory questions, thus avoiding lost data in the incoming data. At the same time, a research information form, which includes information on the content, scope, purpose of the research, and the participants' ability to withdraw from the study if they wish, was added.

Since there might be forms that could be filled incorrectly, forms were delivered to $20 \%$ more participants than needed. 366 participants filled out the forms. Since 127 of the participants were primary school teachers, 120 were middle school, and 119 were teachers working in high schools, 7 forms from middle school participants and 6 forms from high school participants were randomly selected from the analyses to equalize the ratios in the strata to the sample representation ratio. Thus, as calculated in the sample, the number of participants who were primary school teachers was achieved as $127,36 \%$. The number of participants, 
consisting of middle school and high school teachers, provided a 32\% rate of 113 . The total number of participants was 353 . The analyses were based on these numbers.

\section{Reliability Analysis}

Cronbach alpha values were calculated to examine the reliability of the scales used in the study, based on internal consistency. If the alpha coefficient is greater than 0.40 and less than 0.60 , it means that the measurements of the scale are at low reliability if greater than 0.60 and less than 0.80 are quite reliable, and greater than 0.80 and less than 1.00 are highly reliable (Alpar, 2013, as cited in Yıldız \& Uzunsakal, 2018). Reliability coefficients of the scales are given in Table 1 and Table 2.

Table 1. Cronbach Alpha Reliability Coefficients of the ESPCPS

\begin{tabular}{ccc}
\hline Scale & Number of items & Cronbach's Alpha \\
\hline ESPCPS & 18 & 0.66 \\
\hline
\end{tabular}

According to Table 1, the Cronbach alpha value of the scale of effectiveness of school principals in the communication process was determined as 0.66 . According to this result, it can be said that the reliability of the scale of effectiveness of school principals in the communication process is sufficient.

Table 2. Cronbach Alpha Reliability Coefficients of the PCSSF

\begin{tabular}{cccc}
\hline Scale & Dimension & Number of items & Cronbach alfa \\
\hline \multirow{3}{*}{ PCSSF } & Self-efficacy & 3 & 0.80 \\
& Hope & 4 & 0.84 \\
& Resilience & 3 & 0.58 \\
& Optimism & 2 & 0.80 \\
& & 12 & 0.88
\end{tabular}

According to Table 2, the Cronbach's alpha coefficients calculated for self-efficacy, hope, resilience, and optimism of the short form of the psychological capital scale were $0.80 ; 0.84 ; 0.58 ; 0.80$, respectively. Accordingly, self-efficacy and optimism were quite reliable, and hope was highly reliable. On the other hand, the resilience sub-dimension was at a low level of reliability. The overall alpha coefficient of the scale was calculated as 0.88 . According to the results, it can be said that the calculated internal consistency coefficients of the psychological capital scale short form were sufficient.

\section{Data Analysis}

The skewness and kurtosis coefficients were examined to calculate the effectiveness of school principals in the communication process and psychological capital scale short-form scales whether the scores obtained from the scales used in this study were normally distributed or not. The fact that the coefficient of skewness is less than \pm 3 and the kurtosis coefficient is less than \pm 10 is considered sufficient to assume that the data are distributed normally (Kline, 2011). The skewness and kurtosis coefficients for all scales ranged from -1 to +1 . According to the results, it can be said that the data showed a normal distribution.

To determine the levels of teachers participating in the study related to the variables of the study, it was assumed that the intervals in the measurement tool were equal, the effectiveness of school principals in the communication process (4/5), psychological capital (5/6). First, the lower and upper limits for the options were determined. Accordingly, the scoring of the statements in the effectiveness of school principals in the communication process; between 1.00-1.79 was calculated as "very low," between 1.80-2.59 as "low," between 2.60-3.39 as "medium," between 3.40-4.19 as "high" and between 4.20-5.00 as "very high." T scoring of the statements in the psychological capital short-form scale was 1.00-1.83 "very low," 1.84-2.67 "low," 2.684.35 "medium" (2.68-3.51 partially disagree / 3.52-4.35 partially agree), 4.36-5.19 " high, " calculated as 5.20-6.00" very high." Besides, in accordance with the purpose of the study, the ANOVA test was used to determine the difference between groups. Pearson correlation analysis was performed to determine the relationship between the effectiveness of school principals in the communication process and the psychological capital of teachers. A simple linear regression analysis was conducted to determine the effect of school principals 'effectiveness in the communication process on teachers' psychological capital.

\section{FINDINGS}

The results of the descriptive statistical analysis conducted to determine the average scores of the teachers participating in the study. Teachers' perceptions of the effectiveness of school principals in the communication process (3.45 \pm .37$)$ were seen at a high level. When the average psychological capital levels of teachers were examined, self-efficacy sub-dimension was high (5.02 \pm .71 ); hope sub-dimension was high (4.91 \pm .71$)$; resilience sub-dimension was high (4.50 \pm .74$)$; optimism sub-dimension was high (4.66 \pm .97). It was observed that they agreed with the psychological capital general score at a high level (4.79 \pm .62$)$. 
Table 3. ESPCPS and PCSSF Scores, Standard Deviation and ANOVA Results by School Levels

\begin{tabular}{|c|c|c|c|c|c|c|}
\hline Variables & School level & $\mathrm{N}$ & $\bar{X}$ & Std & $\mathrm{F}$ & $P$ \\
\hline & Primary & 127 & 3.47 & 0.37 & & \\
\hline \multirow[t]{3}{*}{ ESPCPS } & Secondary & 113 & 3.36 & 0.32 & 4.58 & 0.01 \\
\hline & High school & 113 & 3.50 & 0.38 & & \\
\hline & Primary & 127 & 4.99 & 0.75 & & \\
\hline \multirow[t]{3}{*}{ Self-efficacy } & Secondary & 113 & 4.94 & 0.70 & 2.38 & 0.09 \\
\hline & High school & 113 & 5.13 & 0.63 & & \\
\hline & Primary & 127 & 5.00 & 0.76 & & \\
\hline \multirow[t]{3}{*}{ Hope } & Secondary & 113 & 4.80 & 0.64 & 2.43 & 0.08 \\
\hline & High school & 113 & 4.92 & 0.69 & & \\
\hline & Primary & 127 & 4,55 & 0,78 & & \\
\hline \multirow[t]{3}{*}{ Resilience } & Secondary & 113 & 4,43 & 0,73 & 0,80 & 0,44 \\
\hline & High school & 113 & 3,46 & 0,68 & & \\
\hline & Primary & 127 & 4.78 & 1.05 & & \\
\hline \multirow[t]{3}{*}{ Optimism } & Secondary & 113 & 4.57 & 0.96 & 1.45 & 0.23 \\
\hline & High school & 113 & 4.62 & 0.87 & & \\
\hline & Primary & 127 & 3.35 & 0.76 & & \\
\hline \multirow[t]{2}{*}{ PCSSF overall } & Secondary & 113 & 3.40 & 0.73 & 0.83 & 0.16 \\
\hline & High school & 113 & 3.38 & 0.71 & & \\
\hline
\end{tabular}

According to Table 3, it was understood that self-efficacy, hope, resilience, optimism, and the total score of psychological capital did not differ significantly by school levels $(p>0.05$ ). It has been determined that the psychological capital perceptions of the teachers working in primary, secondary, and high schools are similar according to the school levels. On the other hand, it was seen that teachers' perceptions of the effectiveness of school principals in the communication process showed a significant difference according to school levels $(p<0.05)$. ANOVA test results regarding this difference are given in Table 4.

Table 4. ESPCPS ANOVA Results

\begin{tabular}{|c|c|c|c|c|c|c|c|c|c|c|}
\hline \multirow[b]{2}{*}{ Score } & \multicolumn{4}{|c|}{ N, SS ve $\overline{\mathbf{X}}$ Values } & \multicolumn{6}{|c|}{ ANOVA Results } \\
\hline & Group & $\mathrm{N}$ & $\overline{\mathbf{x}}$ & $\mathrm{SE}_{\mathrm{x}}$ & Var. K. & K.T. & Std & K.O. & $\mathrm{F}$ & $\mathrm{p}$ \\
\hline \multirow{4}{*}{ ESPCPS } & Primary & 127 & 3,47 & 0,03 & $\begin{array}{l}\text { Between } \\
\text { G. }\end{array}$ & 1,20 & 0,37 & 0,60 & \multirow{4}{*}{4.58} & \multirow{4}{*}{0.01} \\
\hline & Secondary & 113 & 3.36 & 0.03 & Within G. & 45.96 & 0.32 & 0.13 & & \\
\hline & \multirow[t]{2}{*}{ High school } & 113 & 3.50 & 0.03 & \multirow[t]{2}{*}{ Total } & \multirow[t]{2}{*}{47.17} & 0.38 & & & \\
\hline & & 353 & 3.45 & 0.01 & & & 0.36 & & & \\
\hline
\end{tabular}

The total score of the school principals' effectiveness in the communication process was determined as 0.23 as a result of Levene's test. ( $p>0.05$ ). This result showed that the variance is distributed homogeneously. Also, the Gabriel test can be used to test the difference in cases where the number of participants between groups was not exactly equal and close to each other (Field, 2005). For this reason, the Gabriel test, one of the post hoc analyses, was used to understand which school level showed the difference. Results are given in Table 5.

Table 5. Post-Hoc Gabriel Test Results on the ESPCPS Scores

\begin{tabular}{ccccc}
\hline School level (i) & School level $(\mathrm{j})$ & Mean D. $(\mathrm{i}-\mathrm{j})$ & $\mathrm{SE}_{\mathrm{x}}$ & $\mathrm{p}$ \\
\hline Primary & Secondary & .10201 & 0.4 & .087 \\
& High school & -.03909 & 0.4 & .788 \\
\hline
\end{tabular}




\begin{tabular}{ccccc}
\hline Secondary & Primary & -.10201 & 0.4 & .087 \\
& High school & $-.14110^{*}$ & 0.4 & .011 \\
\hline High school & Primary & .03909 & 0.4 & .788 \\
& Secondary & $.14110^{*}$ & 0.4 & .011 \\
\hline
\end{tabular}

$$
{ }^{*} \mathrm{p}<0.05
$$

According to Table 5, it was seen that teachers' perceptions of the effectiveness of school principals in the communication process differ among middle school and high school teachers. After this analysis, in accordance with the purpose of the study, Pearson correlation analysis was conducted to test the relationship between the effectiveness of school principals in the communication process and the psychological capital of teachers. The results obtained are given in Table 6.

Table 6. Pearson's Correlation Coefficients Regarding the Relationship Between ESPCPS and PCSSF

\begin{tabular}{|c|c|c|c|c|c|c|c|}
\hline & Variables & 1. & 2. & 3. & 4. & 5. & 6. \\
\hline 1. & ESPCPS & 1 & & & & & \\
\hline 2. & Self efficacy & $.318^{* *}$ & 1 & & & & \\
\hline 3. & Hope & $.376 * *$ & $.636 * *$ & 1 & & & \\
\hline 4. & Optimism & $.306 * *$ & $.402 * *$ & $.585^{* *}$ & 1 & & \\
\hline 5. & Resilience & $.186 * *$ & $.475^{* *}$ & $.608^{* *}$ & $.503 * *$ & 1 & \\
\hline 6. & PCSSF Overall & $.370 * *$ & $.776 * *$ & $.899 * *$ & $.751^{* *}$ & $.798 * *$ & 1 \\
\hline & $\bar{X}$ & 3.45 & 5.02 & 4.91 & 4.66 & 4.50 & 4.79 \\
\hline & SS & 0.36 & 0.70 & 0.70 & 0.97 & 0.73 & 0.61 \\
\hline
\end{tabular}

${ }^{* *} \mathrm{p}<0.01 \mathrm{~N}=353$

According to Table 6, the scores of effectiveness of school principals in the communication process and resilience $(r=0.186 ; p$ $<0.01)$ were low, self-efficacy $(r=0.318 ; p<0.01)$, hope $(r=0.376)$; $p<0.01)$, optimism $(r=0.306 ; p<0.01)$, and psychological capital scale total scores $(r=0.370 ; p<0.01)$ were found to have moderately positive significant relationships. According to this result, as the effectiveness of school principals in the communication process increased, teachers' psychological capital also increased.

Table 7. Results of Regression Analysis to Test the ESPCPS on PCSSF of Teachers'

\begin{tabular}{lccccc}
\hline Variable & $\mathrm{B}$ & $\begin{array}{l}\text { Standart } \\
\text { Error }\end{array}$ & $\mathrm{B}$ & $\mathrm{t}$ & $\mathrm{P}$ \\
\hline (Independent) & 2.64 & 0.29 & 9.10 & 0.00 \\
ESPCPS & 0.62 & 0.08 & 0.37 & 7.46 & 0.00 \\
\hline $\mathrm{R}=0.370$ & \multicolumn{2}{c}{$\mathrm{R}^{2}=0,137$} & $\mathrm{~F}=55.767$ & $p<0.001$ \\
\hline
\end{tabular}

Dependent variable= Psychological Capital

According to Table 7, it was understood that the effectiveness of school principals in the communication process had a significant relationship with psychological capital $(R=0.370 ; F=55.767 ; p<0.001)$. The effectiveness of school principals in the communication process explained $13 \%$ of the change in teachers' psychological capital. When the significance values of the standardized beta coefficients were examined, it was understood that the effectiveness of school principals in the communication process $(\beta=0.37 ; p<0.01)$ was a significant predictor of psychological capital. The effectiveness of school principals' effectiveness in the communication process had a positive effect on psychological capital.

\section{DISCUSSION, CONCLUSION, AND RECOMMENDATIONS}

In this study, the effects of the effectiveness of school principals in the communication process on the levels of teachers' psychological capital were examined. Because of COVID-19, face-to-face education was largely suspended in almost all countries. This situation led authorities to search for different solutions, with distance education has emerged as the key alternative | Kastamonu Education Journal, 2021, Vol. 29, No. 31 
(Karaköse \& Demirkol, 2021). Soon fully-online education started to play an important role in education systems (Karaköse, 2021). So, teachers started to work from home alone, and the school principals worked at schools communicating with teachers online. This online education process is seen as a panacea for the education crisis (Dhawan, 2020). Therefore, it is thought that effective communication and teachers' psychological capital have become more important.

First of all, teachers' perceptions of school principals' communication process effectiveness and teachers' psychological capital levels were analyzed. Accordingly, it was found that teachers' perception of the effectiveness of the school principals in the communication process was high. According to this result, although the effectiveness of school principals in communication processes can be evaluated as sufficient, it can be said that they were not at a very high level. Similarly, Çınar (2010) supports this result. Considering the importance of school principals in the realization of the goals of the school, workshops can be developed to improve the communication process of school principals. The content should be created by taking the opinions of school principals. It is evident that digital communication tools gained more importance, especially as a result of the COVID-19. In this context, the content of the workshops can include the use of digital communication tools.

On the other hand, teachers' psychological capital levels were also found to be very high. The self-efficacy sub-dimension, one of the sub-dimensions of psychological capital, is seen at the highest level. The research results of Keser and Kocabaş (2014) and Tösten and Özgan (2017) reveal that teachers' psychological capital is at a very high level. Considering the importance of psychological capital as an individual resource for employees to achieve the goals of the organization, it can be said that it is a positive result that teachers' psychological capital levels and especially their self-efficacy are very high in achieving the goals of schools during the COVID-19.

In line with the aims of the study, it was tested whether the effectiveness of the communication process of school principals and the psychological capital of teachers differed according to school levels. Accordingly, the psychological capital of teachers did not differ according to school levels. On the other hand, the effectiveness of the communication process of school principals varied according to secondary school and high school levels. In some studies, no difference was found in the effectiveness of the communication process of school principals based on primary school teachers and branch teachers (Kösterelioğlu \& Argon, 2010; Çınar, 2010). In this study, a difference was determined according to school levels. However, considering that the teachers working in secondary and high schools are branch teachers, qualitative research can be conducted on why the difference between the levels occurs.

In the study, a moderately significant positive relationship was found between the communication process effectiveness of school principals and teachers' psychological capital and its sub-dimensions. In the analyses made based on these results, it was seen that the effectiveness of school principals in the communication process explained $13 \%$ of teachers' psychological capital and had a positive effect as a significant predictor. This shows that if school principals manage the communication process effectively, especially during the COVID-19, the psychological capital of teachers will also increase. Therefore, it can be said that the effectiveness of the communication process of school principals and the work of teachers individually due to distance education are important for achieving the goals of the school. Psychological capital, one of the individual resources, is the concept of positive organizational behavior in organizations that emerges from positive psychology (Luthans \& Youssef, 2007). This core structure, taken from the broaden and build theory, has theoretically contributed to individual resources with its sub-dimensions of self-efficacy, hope, optimism, and resilience (Luthans et al., 2007). According to the broaden and build theory, positive emotions broaden people's repertoire of thought and action and constitute permanent individual resources (Frederickson, 2004). As a new situation, the access of students, especially in the context of communication in distance education and the communication problems experienced by school principals and teachers, unlike face-to-face education, is the main problem (Külekçi Akyavuz \& Çakın, 2020; Çakın \& Külekçi Akyavuz, 2020). According to the theory of broaden and build theory, it can be said that positive emotions are important to improve the psychological capital level of teachers to find new solutions to usual and unusual problems because individuals become more resilient with the effect of positive emotions (Frederickson, 2004). If the managers express what they expect from the employees through an effective communication process, the positive feelings of the employees towards the job are reinforced (Eroğlu, 2013). According to the psychological perspective, the communication between the receiver and the sender can be determined by the characteristics of the individuals (Gizir \& Şimşek, 2005). According to this perspective, there are numerous stimuli in the communication environment of individuals, and individuals can choose these stimuli according to their perceptions, interests, and attitudes (Durğun, 2006). Therefore, school principals should be aware of this perspective in the communication process because the pandemic may have caused teachers to have a negative perception and attitude about the situation. Therefore, the negative statements of school principals about the process may affect teachers who have negative feelings especially due to the pandemic more and cause their psychological capital and thus their performance to decrease. Besides, since direct observation of internal processes is limited according to the psychological perspective (Jensen 2003 cited in Durgun, 2006), it is thought that it will be effective for school principals to conduct a positive communication process regarding the pandemic. According to the psychological perspective, it is possible that negative discourses negatively affect teachers. In this context, it can be thought that the effectiveness and positive discourse of school principals in the communication process can create positive emotions. These feelings can play an important role in reaching the goals of school in the pandemic process by contributing to the development of teachers' psychological capital. In this respect, psychological capital can be chosen as one of the subjects that teachers make presentations on during the seminar periods of schools. In connection with this, school principals can also make a presentation by researching the communication process or organize a workshop on these issues with the decision of the district national education directorate. 
Since this research was carried out during the COVID-19, online data were collected due to teachers not being present in schools. Since the data were collected only from the district of Güngören, the results of the research can only be generalized to this district. Similar research can be done in other districts or throughout the province. Another limitation of the study is that it is not known whether the participants were randomly selected by the school principals or not. For this reason, similar research can be repeated by collecting data face to face. Also, research was conducted during the pandemic. For this reason, when the pandemic is over, similar research can be conducted, and the results obtained can be compared with the results of this research.

As a result, in this study, the effect of the effectiveness of school principals in the communication process on teachers' psychological capital was examined. As a result of the research, although the effectiveness of the communication process of school principals was found to be high, it was seen that it should be improved. On the other hand, the psychological capital levels of the teachers have been determined at a very high level, and it seems to be a positive result in the pandemic period when the realization of the goals of the school becomes difficult. For the study, a moderately positive and significant relationship was found between the effectiveness of school principals in the communication process and the psychological capital of teachers, and it was understood that the effectiveness of school principals in the communication process as a predictor of teachers' psychological capital.

\section{Declaration of Conflicting Interests}

The author(s) declared no potential conflicts of interest with respect to the research, authorship, and/or publication of this article.

\section{Funding}

The author(s) received no financial support for the research, authorship, and/or publication of this article.

\section{Statements of publication ethics}

I/We hereby declare that the study has not unethical issues and that research and publication ethics have been observed carefully.

\section{Author contribution statements}

İbrahim Kocabaş encouraged Aydın Karabay to do this research on teachers and school administrators during the COVID-19 process, and he helped during the study. Aydın Karabay conducted the research from beginning to end and turned it into a report. Mithat Korumaz read each step in detail and gave feedback. He also contributed significantly to the research in determining the sample and statistical analysis.

\section{Ethics Committee Approval Information}

This research has Yıldız Technical University Ethics Committee Approval Document dated 09/01/2021 and numbered E.2101090035.

\section{REFERENCES}

Acaray, A . (2018). Örgütsel muhalefet üzerine pozitif psikolojik sermayenin etkisi: eğitim sektöründe bir çalışma . Anemon Muş Alparslan Üniversitesi Sosyal Bilimler Dergisi, 6 ICEESS' 18, 83-91.

Akçadağ, T. (2014). Yönetim süreçleri. R. Sarpkaya (Ed.), Türk eğitim sistemi ve okul yönetimi (s.174-196). Anı.

Başaran, İ. E. (1994). Eğitim Yönetimi. Kadıŏlu Matbaası.

Bolelli, M. (2020). Psikolojik sermayenin öznel iyi oluş üzerindeki etkileri: Türkiye'den bir araştırma. International Journal of Management and Administration, 4(8), 245-259. https://doi.org/10.29064/ijma.763064

Bursalıoğlu, Z. (2015). Okul yönetiminde yeni yapı ve davranış. Pegem

Carr, A. (2015). Pozitif psikoloji. Kaknüs.

Çakın, M., \& Külekçi Akyavuz, E. (2020). Covid-19 süreci ve eğitime yansıması: öğretmen görüşlerinin incelenmesi. International Journal of Social Sciences and Education Research, 6 (2), 165-186. https://doi.org/10.24289/ijsser.747901

Creswell, J.W. (2012). Educational research. Pearson.

Cüceloğlu, D. (2002). "Keşke”"siz bir yaşam için: Iletişim donanımları. Remzi

Çınar, O. (2010). Okul müdürlerinin iletişim sürecindeki etkililiği. Dumlupınar Üniversitesi Sosyal Bilimler Dergisi, 26, $267-276$.

Dhawan, S. (2020). Online Learning: A Panacea in the Time of COVID-19 Crisis. Journal of Educational Technology Systems, 49(1), 5-22.

Dökmen, Ü. (2006). Iletişim çatışmaları ve empati. Sistem

Durğun, S. (2006). Örgüt kültürü ve örgütsel iletişim. Yüzüncü Yıl Üniversitesi, Eğitim Fakültesi Dergisi, 3(2), $112-132$.

Ekiz, D. (2015). Bilimsel araştırma yöntemleri. Anı. 
Erdoğan, ì. (2014). Eğitim ve okul yönetimi. Alfa.

Eroğlu, E . (2013). Örgütsel iletişimin iş görenlerin duygu gösterimlerinin yönetimine olan etkisi . Selçuk iletişim, 6 (3) , 18-33.

Eren, E. (2016). Yönetim ve organizasyon. Beta

Eren, E. (2017). Örgütsel davranış ve yönetim psikolojisi. Beta

Erkmen, T., \& Esen E. (2012). Psikolojik sermaye konusunda 2003-2011 yıllarında yapılan çalışmaların kategorik olarak incelenmesi. Mustafa Kemal Üniversitesi Sosyal Bilimler Enstitüsü Dergisi, 9(19), 89-103.

Field, A. (2005). Discovering statistics using SPSS. Sage publications.

Fraenkel, J.R., \& Wallen, N. E. (2009). How to design and evaluate research in education. McGraw-Hill Higher Education.

Frederickson, B.L. (2001). The role of positive emotions in positive psychology: The broaden-and-build theory of positive emotions. Am Psychol, 56(3), 218-226.

Frederickson, B.L. (2004). The broaden-and-build theory of positive emotions. Philosophical Transactions of The Royal Society, 359(1444), 1367-1377.

Gillham, J., \& Seligman, P. (1999). Footsteps on the road to a positive psychology. Behaviour Research and Therapy, 37, $163-173$.

Gizir, S., \& Şimşek, H. (2005). Communication in an academic context. Higher Education, 50, 197-221.

Gorgievski, M.J., Halbesleben, J.R.B. \& Bakker, A.B. (2011). Introduction Expanding the boundaries of psychological resource theories. Journal of Occupational and Organizational Psychology, 84, 1-7.

Güngören Kaymakamlığı, (2020) http://www.Güngören.gov.tr/egitim-kultur

Hoy, W., \& Miskel, C. (2015). Okullarda iletişim. S.Akbaba \& S. Turan (Çev. Ed.), Eğitim yönetimi: teori araştırma ve uygulama (s 340-373).

Karakaya, i. (2014). Bilimsel araştırma yöntemleri. A.Tanrıöğen (Ed.), Bilimsel araştırma yöntemleri (s.55-84). Anı.

Karaköse, T. (2021). The impact of the COVID-19 epidemic on higher education: Opportunities and implications for policy and practice. Educational Process: International Journal, 10(1), 7-12.

Karaköse, T., \& Demirkol, M. (2021). Exploring the emerging COVID-19 research trends and current status in the field of education: a bibliometric analysis and knowledge mapping. Educational Process: International Journal, 10(3), 7-27.

Karaköse, T., \& Kocabaş, í. (2009). An investigation of ethical culture in educational organizations. African Journal of Business Management, 3(10), 504-510.

Karasar, N. (2016). Bilimsel araştırma yöntemi. Nobel.

Keleş, H. N. (2011). Pozitif psikolojik sermaye: tanımı, bileşenleri ve örgüt yönetimine etkileri. Organizasyon Ve Yönetim Bilimleri Dergisi, 3(2), 343-350.

Keser, S., \& Kocabaş, İ. (2014). İlköğretim okulu yöneticilerinin otantik liderlik ve psikolojik sermaye özelliklerinin karşılaştırılması. Kuram ve Uygulamada Eğitim Yönetimi, 1(1), 1-22.

Kline, R. B. (2011). Principles and practice of structural equation modeling. NY: Guilford.

Kocabaş, I. (2014). Örgütsel iletişim. S. Turan (Ed.), Eğitim yönetimi teori araştırma ve uygulama (s.189-224). PegemAkademi.

Koçel, T. (2018). Işsletme yöneticliği. Beta

Kösterelioğlu, M., \& Argon, T. (2010). Okul yöneticilerinin iletişim sürecindeki etkililiğine ilişkin öğretmen algıları. Ahi Evran Üniversitesi Eğitim Fakültesi Dergisi, 11(1), 1-17.

Külekçi Akyavuz, E., \& Çakın, M. (2020). Covid-19 Salgınının Eğitime Etkisi Konusunda Okul Yöneticilerinin Görüşleri. Turkish Studies, 15(4),723-737. https://dx.doi.org/10.7827/TurkishStudies.44140

Lunenburg, C., \& Ornstein, C. (2013). Eğitim yönetimi. G. Arastaman (Çev. Ed.), Nobel

Luthans, F., Luthans, K. W., \& Luthans, B. C. (2004). Positive psychological capital: Beyond human and social capital. Management Department Faculty Publications 47(1), 45-50. http://digitalcommons.unl.edu/managementfacpub/145

Luthans, F., \& Jensen, S.M. (2002). Hope: A new positive strength for human resource development. Human Resource Development Review, 1(3), 57-62.

Luthans F., Youssef C., \& Avolio B. (2006). Psychological capital development: toward a micro-intervention, Journal of Organizational Behaviour, 27(3), 387-393.

Luthans, F., Avolio, B.J., Avey, J.B. \& Norman, S.M. (2007). Positive psychological capital: measurement and relationship with performance and satisfaction. Personnel Psychology, 60, 541-572

Luthans, F., \& Youssef, C. (2007). Emerging positive organizational behavior. Leadership Institute Faculty Publications, 33(3), 321349.

Luthans, F., \& Youssef, C. M. (2004). Human, social, and now positive psychological capital management: Investing in people for competitive advantage. Management Department Faculty Publications, 33(2), $143-160$. https://digitalcommons.unl.edu/managementfacpub/154 
Mcmillan, J. \& Schumacher S. (2014). Research in Education: Evidence-Based Inquiry, Pearson New International Edition. Mevzuat, (2020). https://www.mevzuat.gov.tr/mevzuat?MevzuatNo=19942\&MevzuatTur=7\&MevzuatTertip=5

Milli Eğitim Bakanlığı, (2020). Haber arşivi.

https://www.meb.gov.tr/bakan-selcuk-koronaviruse-karsi-egitim-alaninda-alinan-tedbirleri-acikladi/haber/20497/tr

https://www.meb.gov.tr/uzaktan-egitimle-ilgili-surec-hafta-ici-simulasyonlarla-anlatilacak/haber/20513/tr)

https://www.meb.gov.tr/uzaktan-egitim-bakan-selcukun-verdigi-dersle-basladi/haber/20578/tr

https://www.meb.gov.tr/uzaktan-egitim-30-nisana-kadar-devam-edecek/haber/20585/tr

https://www.meb.gov.tr/uzaktan-egitim-31-mayisa-kadar-devam-edecek/haber/20803/tr

https://www.meb.gov.tr/sartlar-uygun-olursa-ders-zili-31-agustosta-calacak/haber/21240/tr

https://www.meb.gov.tr/18-eylule-kadar-surecek-uzaktan-egitim-doneminin-yol-haritasi/haber/21499/tr

https://www.meb.gov.tr/okullarda-yuz-yuze-egitimde-ikinci-asama-12-ekim-pazartesi-gunu-basliyor/haber/21776/tr

https://www.meb.gov.tr/okullarda-yuz-yuze-egitimde-ucuncu-asama-2-kasim-pazartesi-gunu-basliyor/haber/21861/tr

https://www.meb.gov.tr/ara-tatilin-ardindan-ders-zili-23-kasim-pazartesi-gunu-uzaktan-egitimle-caliyor/haber/22007/tr

Oruç, E. (2018). Psikolojik sermaye ölçeği kısa formunun Türkçe uyarlaması: geçerlik ve güvenirlik çalışması. Turkish Studies Economics, Finance and Politics, 13(14), 141-151. doi Number: http://dx.doi.org/10.7827/TurkishStudies.13618

Önen, Ö. (2016). Yönetim süreçleri. E.Doğan Kılıç (Ed.), Türk eğitim sistemi ve okul yönetimi (s. 87-108). Eğiten Kitap.

Özdemir, M. (2018). Eğitim yönetimi: Alanın temelleri ve çağdaş yönelimler. Anı.

Özmen, F., \& Yörük, S. (2007). Okul yöneticilerinin iletişim sürecindeki etkililiği ölçeğinin geliştirilmesi. Milli Eğitim, 36(174), 88105.

Seligman, M. (1998). Learned optimism. Pocket books.

Seligman, M. (2002). Positive psychology, positive prevention, and positive therapy. C.R.

Sönmez, V., \& Alacapınar, F.G. (2014). Örneklendirilmiş bilimsel araştırma yöntemleri. Anı.

Synder \& S. J. Lopez (Ed. ), Handbook of positive psychology (s.3-9). Oxford

Sucu, í. (2020). Yeni dünya düzeninde dönüşümün iletişim ve medyadaki ilk adımları: covid-19 sonun başlangıcında yeni bir dijital çağ. Insan ve Sosyal Bilimler Dergisi, 3(2), 556-566. https://dergipark.org.tr/en/pub/johass/issue/57478/772366

Taymaz, H. (2011). Okul yönetimi. Pegem

Tösten, R., \& Özgan, H. (2017). Öğretmenlerin pozitif psikolojik sermayelerine ilişkin algılarının incelenmesi. Elektronik Sosyal Bilimler Dergisi, 16(62), 867-889. https://doi.org/10.17755/esosder.306900

Yamane, T. (2006). Temel örnekleme yöntemleri. A.Esin vd (Çev. Ed.). Literatür

Yıldız, D. \& Uzunsakal, E. (2018). Alan araştırmalarında güvenilirlik testlerinin karşılaştırılması ve tarımsal veriler üzerine bir uygulama. Uygulamalı Sosyal Bilimler Dergisi, 1, 14-28. 